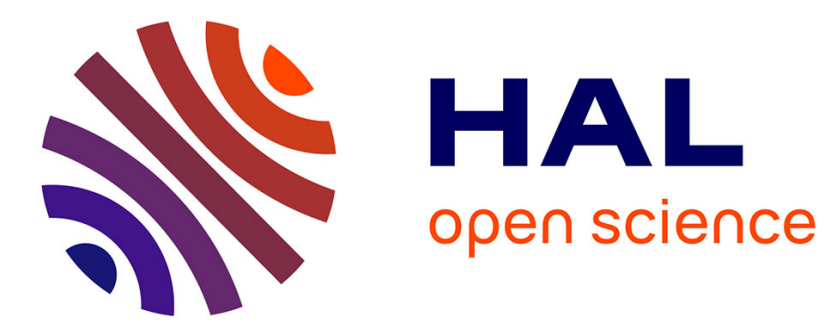

\title{
Ruminococcal cellulosomes: molecular Lego to deconstruct microcrystalline cellulose in human gut \\ Gurvan Michel
}

\section{To cite this version:}

Gurvan Michel. Ruminococcal cellulosomes: molecular Lego to deconstruct microcrystalline cellulose in human gut. Environmental Microbiology, 2015, 17 (9), pp.3113-3115. 10.1111/1462-2920.12920 . hal-02137960

\section{HAL Id: hal-02137960 \\ https://hal.science/hal-02137960}

Submitted on 23 May 2019

HAL is a multi-disciplinary open access archive for the deposit and dissemination of scientific research documents, whether they are published or not. The documents may come from teaching and research institutions in France or abroad, or from public or private research centers.
L'archive ouverte pluridisciplinaire HAL, est destinée au dépôt et à la diffusion de documents scientifiques de niveau recherche, publiés ou non, émanant des établissements d'enseignement et de recherche français ou étrangers, des laboratoires publics ou privés. 
1 Highlights on: Ben David et al (2015) Ruminococcal cellulosome systems from rumen to

2 human. Environmental Microbiology

3

4

5 Ruminococcal cellulosomes: molecular Lego to deconstruct microcrystalline cellulose in

6 human gut

7

8

Gurvan Michel

9

10 Sorbonne Université, UPMC Univ Paris 06, CNRS, UMR 8227, Integrative Biology of

11 Marine Models, Station Biologique de Roscoff, CS 90074, F-29688, Roscoff cedex, Bretagne,

12 France

13 For correspondence: Station Biologique de Roscoff, Place Georges Teissier, 29688, Roscoff,

14 Bretagne, France. Tel.: 33-298-29-23-30; Fax: 33-298-29-23-24; E-mail: gurvan.michel@sb-

15 roscoff.fr. 
Plants (and also algae in East Asian cuisine) constitute the bases of human diet. These

2 photosynthetic organisms are characterized by their abundance in diverse polysaccharides, which constitute their cell walls and carbon storage (Popper et al., 2011). Paradoxically, human ability to digest complex carbohydrates is very limited and restricted to the assimilation of some disaccharides (e.g. lactose, sucrose) and starch. These catabolic limitations are fortunately compensated by the capacities of symbiotic gastrointestinal microbes to degrade most dietary polysaccharides (El Kaoutari et al., 2013). Human gut microbiota is usually dominated by the Firmicutes and the Bacteroidetes form the second most abundant bacterial group (Ley et al., 2008). Nonetheless, the mechanisms of polysaccharide assimilation have been mainly studied in gut Bacteroidetes. From the seminal works of Salyers and coworkers on the starch utilization system (Sus) of Bacteroides thethaiotaomicron (Anderson and Salyers, 1989; Cho and Salyers, 2001) has emerged the more general notion of Polysaccharide Utilization Loci (PUL). These gene clusters encode most proteins needed for the uptake and degradation of a specific polysaccharide and notably include the crucial susC-like (TonB-dependent transporter) and susD-like (an associated carbohydrate-binding lipoprotein) genes (Koropatkin et al., 2012). In the last years several PULs with new substrate specificity have been characterized in Bacteroidetes such as: plant fructans (Sonnenburg et al., 2010), porphyrans from red algae (Hehemann et al., 2010), alginates from brown algae (Thomas et al., 2012), plant xyloglucans (Larsbrink et al., 2014) and yeast $\alpha$-mannans (Cuskin et al., 2015). The frequency of these PULs in the gut microbiomes tends to correlate with the prevalence of their respective substrate in diet: from culturally-restricted PULs in the case of porphyrans and alginates to largely distributed PULs for mannan and xyloglucan (Cuskin et al., 2015).

If a polysaccharide could be considered as omnipresent in human diet, it would without doubt be cellulose, which is conserved from algae to flowering plants (Popper et al., 2011). 
1 However cellulose-degrading bacteria in human gut remain relatively unexplored. Cellulolytic

2 bacteria are present in human gut but their community structure varies with the presence of methanogen archae. In non-methane-excreting individuals the cellulolytic community is dominated by Bacteroidetes species. In methane-excreting individuals the main cellulosedegrading bacteria are represented by Firmicutes (Ruminococcus and Enterococcus species) (Robert and Bernalier-Donadille, 2003; Chassard et al., 2010). The rationale behind this dichotomy is that cellulose fermentation by the Firmicutes isolates releases large amount of $\mathrm{H}_{2}$ which is consumed by methanogens, while the cellulotytic Bacteroides strains do not produce $\mathrm{H}_{2}$. This interplay between $\mathrm{H}_{2}$-producing and $\mathrm{H}_{2}$-consuming microbes seems essential for an efficient fermentation of cellulose (Robert et al., 2001; Chassard et al., 2010). In terms of cellulose degradation other points are also essential. The Bacteroides isolates, including the representative species B. cellulosilyticus strain CRE21 ${ }^{(\mathrm{T})}$ (Robert et al., 2007), are able to degrade native cellulose but not the purified microcrystalline fraction, indicating that these microorganisms can efficiently degrade only amorphous cellulose. In contrast, the Firmicutes isolates are able to assimilate all types of cellulose, including microcrystalline fibers (Chassard et al., 2010). One of these strains defines a new Ruminococcus species, $R$. champanellensis (Chassard et al., 2012). So for once, the key carbohydrate degraders in human gut are not to be found among the Bacteroidetes, but among the Firmicutes! How to explain such an efficiency difference between cellulolytic Bacteroidetes and Firmicutes?

In this issue of Environmental Microcobiology Ben David and coworkers give an exciting answer to this question. An in-depth bioinformatic analysis of $R$. champanellensis genome has revealed 20 putative cohesin modules (belonging to 11 scaffoldin proteins, from ScaA to ScaK) and 64 putative dockerin modules, suggesting the existence of cellulosomes in the human gut ecosystem. Cellulosomes are protein complexes including non-catalytic coreproteins (scaffoldin) which recruit multiple cellulolytic enzymes through a unique molecular 
1 interaction between two protein modules referred to as cohesin and dockerin (Smith and

2 Bayer, 2013). In the basic structure of a cellulosome, the type-I dockerins of the modular

3 (hemi)cellulolytic enzymes bind the type-I cohesins of the scaffoldins (Figure 1). Type-II

4 dockerins are localized in the C-terminal region of the scaffoldins and attach the cellulosome

5 to the bacterial cell surface through a specific interaction with the type-II cohesin of

6 anchoring proteins which are themselves covalently bound to the peptidoglycan. The first cellulosome was discovered in the thermophilic bacterium Clostridium thermocellum 30 years ago (Bayer et al., 1983; Lamed et al., 1983) and similar supramolecular complexes were also found in the bovine rumen bacterium Ruminococcus flavefaciens and extensively characterized (Flint et al., 2008). To demonstrate the reality of cellulosomes in human gut, Ben David and coworkers have recombinantly expressed the 20 cohesins of $R$. champanellensis and a representative selection of 24 dockerins. Using an elegant protein microarray approach, they have identified 64 specific interactions among the 480 possible interactions. Based on these experimental evidences, the authors have proposed and discussed a model for the cellulosome complexes of $R$. champanellensis. The most surprising result is the existence of two types of cellulosomes: (i) cell-attached complexes in which the scaffoldin ScaE plays a crucial role, due to its C-terminal sortase signal motif and (ii) cell-free minimal cellulosomes involving the the scaffoldin ScaI which only includes one cohesin module. With such cellulolytic complexes, $R$. champanellensis is indeed well equipped to take advantage of dietary cellulose (although the exact function of the cell-free cellulosome is unclear) and to be a pivotal species for the degradation of microcrystalline cellulose. This remarkable study has also opened diverse biological questions. Does the degradation of cellulose fibers by $R$. champanellensis and related Firmicutes species provide a significant source of energy to the human host considering the short time of digesta retention in comparison to the bovine rumen? Perhaps these Fimicutes play crucial functions more at the community level, opening 
the way to other cellulolytic bacteria more efficient on amorphous cellulose (for instance $B$. cellulosilyticus?). Such a cooperation between gut Firmicutes and Bacteroides species is already known in the case of the degradation of resistant starch (Ze et al., 2012). Finally, the degradation of microcrystalline cellulose likely alters the integrity of the plant cell wall, and thus may facilitate the access of other cell wall components to bacteria specialized in the assimilation of polysaccharides less recalcitrant than cellulose.

\section{Figure Legends}

Figure 1: Example of a cohesin-dockerin complex from Clostridium thermocellum.

Cartoon representation of the complex of the type-I dockerin domain from xylanase 10B and the type-I cohesin 2 from the scaffoldin CipA (PDB code: 1OHZ) (Carvalho et al., 2003). The dockerin and cohesin are colored in magenta and cyan, respectively. Calcium ions bound to the dockerin are represented as yellow spheres. This figure was prepared using PyMol.

\section{References}

Anderson, K.L., and Salyers, A.A. (1989) Genetic evidence that outer membrane binding of starch is required for starch utilization by Bacteroides thetaiotaomicron. $J$ Bacteriol 171: 3199-3204.

Bayer, E.A., Kenig, R., and Lamed, R. (1983) Adherence of Clostridium thermocellum to cellulose. J Bacteriol 156: 818-827.

Carvalho, A.L., Dias, F.M., Prates, J.A., Nagy, T., Gilbert, H.J., Davies, G.J. et al. (2003) Cellulosome assembly revealed by the crystal structure of the cohesin-dockerin complex. Proc Natl Acad Sci USA 100: 13809-13814.

Chassard, C., Delmas, E., Robert, C., and Bernalier-Donadille, A. (2010) The cellulosedegrading microbial community of the human gut varies according to the presence or absence of methanogens. FEMS Microbiol Ecol 74: 205-213.

Chassard, C., Delmas, E., Robert, C., Lawson, P.A., and Bernalier-Donadille, A. (2012) Ruminococcus champanellensis sp. nov., a cellulose-degrading bacterium from human gut microbiota. Int J Syst Evol Microbiol 62: 138-143.

Cho, K.H., and Salyers, A.A. (2001) Biochemical analysis of interactions between outer membrane proteins that contribute to starch utilization by Bacteroides thetaiotaomicron. J Bacteriol 183: 7224-7230. 
Cuskin, F., Lowe, E.C., Temple, M.J., Zhu, Y., Cameron, E.A., Pudlo, N.A. et al. (2015) Human gut Bacteroidetes can utilize yeast mannan through a selfish mechanism. Nature 517: 165-169.

El Kaoutari, A., Armougom, F., Gordon, J.I., Raoult, D., and Henrissat, B. (2013) The abundance and variety of carbohydrate-active enzymes in the human gut microbiota. Nat Rev Microbiol 11: 497-504.

Flint, H.J., Bayer, E.A., Rincon, M.T., Lamed, R., and White, B.A. (2008) Polysaccharide utilization by gut bacteria: potential for new insights from genomic analysis. Nat Rev Microbiol 6: 121-131.

Hehemann, J.H., Correc, G., Barbeyron, T., Helbert, W., Czjzek, M., and Michel, G. (2010) Transfer of carbohydrate-active enzymes from marine bacteria to Japanese gut microbiota. Nature 464: 908-912.

Koropatkin, N.M., Cameron, E.A., and Martens, E.C. (2012) How glycan metabolism shapes the human gut microbiota. Nat Rev Microbiol 10: 323-335.

Lamed, R., Setter, E., and Bayer, E.A. (1983) Characterization of a cellulose-binding, cellulase-containing complex in Clostridium thermocellum. J Bacteriol 156: 828-836.

Larsbrink, J., Rogers, T.E., Hemsworth, G.R., McKee, L.S., Tauzin, A.S., Spadiut, O. et al. (2014) A discrete genetic locus confers xyloglucan metabolism in select human gut Bacteroidetes. Nature 506: 498-502.

Ley, R.E., Lozupone, C.A., Hamady, M., Knight, R., and Gordon, J.I. (2008) Worlds within worlds: evolution of the vertebrate gut microbiota. Nat Rev Microbiol 6: 776-788.

Popper, Z.A., Michel, G., Herve, C., Domozych, D.S., Willats, W.G., Tuohy, M.G. et al. (2011) Evolution and diversity of plant cell walls: from algae to flowering plants. Annu Rev Plant Biol 62: 567-590.

Robert, C., Del'Homme, C., and Bernalier-Donadille, A. (2001) Interspecies H2 transfer in cellulose degradation between fibrolytic bacteria and H2-utilizing microorganisms from the human colon. FEMS Microbiol Lett 205: 209-214.

Robert, C., and Bernalier-Donadille, A. (2003) The cellulolytic microflora of the human colon: evidence of microcrystalline cellulose-degrading bacteria in methane-excreting subjects. FEMS Microbiol Ecol 46: 81-89.

Robert, C., Chassard, C., Lawson, P.A., and Bernalier-Donadille, A. (2007) Bacteroides cellulosilyticus sp. nov., a cellulolytic bacterium from the human gut microbial community. Int J Syst Evol Microbiol 57: 1516-1520.

Smith, S.P., and Bayer, E.A. (2013) Insights into cellulosome assembly and dynamics: from dissection to reconstruction of the supramolecular enzyme complex. Curr Opin Struct Biol 23: 686-694.

Sonnenburg, E.D., Zheng, H., Joglekar, P., Higginbottom, S.K., Firbank, S.J., Bolam, D.N., and Sonnenburg, J.L. (2010) Specificity of polysaccharide use in intestinal bacteroides species determines diet-induced microbiota alterations. Cell 141: 1241-1252.

Thomas, F., Barbeyron, T., Tonon, T., Genicot, S., Czjzek, M., and Michel, G. (2012) Characterization of the first alginolytic operons in a marine bacterium: from their emergence in marine Flavobacteriia to their independent transfers to marine Proteobacteria and human gut Bacteroides. Environ Microbiol 14: 2379-2394.

Ze, X., Duncan, S.H., Louis, P., and Flint, H.J. (2012) Ruminococcus bromii is a keystone species for the degradation of resistant starch in the human colon. Isme $J$ 6: 1535-1543. 


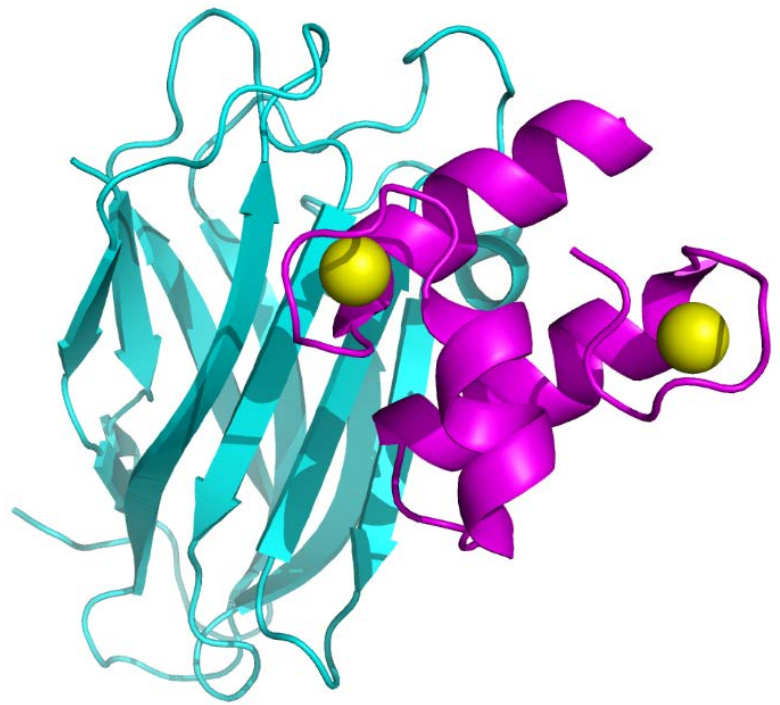

Figure 1 